\title{
Burnout Syndrome In The Covid-19 Pandemic And The Virtualization Of Education
}

\author{
Bellanire Ospina Orejarena $^{a}$, Carmen Rosa Mosquera Murillo ${ }^{b}$, Judith Soledad Yangali Vicente \\ ${ }^{\mathbf{a}, \mathbf{b}}$ Universidad Privada Norbert Wiener \\ ${ }^{\mathrm{c}}$ South American Center for Education and Reserch in Public Health, Universidad Norbert Wiener-Lima, Perú \\ c judith.yangali@uwiener.edu.pe
}

Article History: Received: 10 November 2020; Revised 12 January 2021 Accepted: 27 January 2021; Published online: 5 April 2021

\begin{abstract}
The aim of the research is to determine the relationship between Burnout Syndrome in the framework of the COVID-19 pandemic and the virtualization of education in Colombian official school teachers during the year 2020. The study responds to the mixed approach and sequential design. In its quantitative phase it was deductive-hypothetical, applied, with a non-experimental cross-sectional design, and in its qualitative phase it was inductive, applied with a phenomenologicalhermeneutic design. The data collection techniques used were the survey and the interview. The study population consisted of 1093 teachers from official schools in Floridablanca. For the quantitative approach, a non-probabilistic accidental sample of 110 teachers was used, and for the qualitative approach, a non-probabilistic convenience sample of 10 teachers was used. Among the final considerations it can be said that there is an inverse mean correlation between Burnout syndrome and the virtualization of education in this time of the Covid-19 pandemic; it is therefore considered that the effects of the pandemic have maximized the effects of the aforementioned syndrome on educational actors.
\end{abstract}

Keywords: burnout syndrome, work stress, emotional exhaustion, depersonalization, virtual education

\section{Introduction}

Education by transcendence is responsible for training the human being, however, it is also an organization that involves a series of rules, procedures, policies and management paradigms, currently in the education system teachers are participants in the sufferings of Burnout syndrome, which scientists point it out as chronic stress related to the professional exercise that is developed. This syndrome has been maximized by the presence and experience of the Covid-19 pandemic in the teaching staff. This study focuses on the general objective of determining the relationship between Burnout Syndrome in the context of the COVID-19 pandemic and the virtualization of education in teachers in official Colombian schools - 2020; The specific objectives also determine the relationships between work-related stress, emotional exhaustion, depersonalization, personal fulfilment, disorganization and administrative problems, all within the framework of the COVID-19 pandemic and the virtualization of education.

\section{Burnout}

Burnout syndrome was first introduced in 1974 by Herbert Freudenberg, who observed that his colleagues showed signs of low motivation, energy and interest in their work until they reached high levels of fatigue, anxiety and depression, showing indifference towards patients and feelings of guilt. This type of syndrome manifests itself as a chronic negative response to exposure to different stressors in the workplace, in whose professions a service is provided and an irregular interaction persists between workers and the beneficiaries of their work (Carlotto\&Gonçalves, 2019); this chronic response has four specific characteristics: (i) cognitive attrition (lack of enthusiasm for their work), (ii) affective attrition (emotional and physical exhaustion), (iii) manifestation of feelings of indifference and apathy for the work subjects and colleagues (indolence), (iv) sometimes feelings of guilt arise (Gil-Montea, Viottib\&Conversob, 2017).

After a series of investigations, Maslach and Jackson define this syndrome as a condition that occurs in response to prolonged exposure to both emotional and interpersonal stressors in the workplace; which is composed of three basic dimensions: emotional exhaustion, depersonalisation, which is reflected in the lack of interest and motivation for work and lack of personal fulfilment (Esteras, Chorot\&Sandín, 2014; Rodríguez \&Fernández, 2017 cited by Pinel, Pérez \&Carrión, 2019).

The findings show that burnout syndrome is prevalent in professions linked to work that is carried out in the service of people, which is why teaching is an occupation predisposed to this syndrome, as it involves the development of activities inside and outside the educational institution; The execution of the aforementioned 
responsibilities together with unfavourable professional conditions lead to work overload, one of the main causes of burnout syndrome, which translates into physical, psychological and social conflicts for the teacher with chronic fatigue (Rodríguez, Guevara, \&Viramontes, 2017).

Similarly, a substantial body of work suggests that negative psychosocial factors such as social and organizational problems and problems with students are largely responsible for health impairment, including chronic distress or burnout (Villamar, Juárez, González \& Moreno, 2019); Thus, different researchers state that the lack of didactic and computer resources in the educational institution, the lack of teacher training to meet the different needs of students, the problems and conflict in school coexistence, the adaptation to the different educational guidelines issued by the highest educational authority of a country, the permanent exposure to psychological stress and the lack of social support, are triggers of burnout syndrome (Castillo, Álvarez, Estevan, Queralt\& Molina, 2017; Espinoza, Tous\& Vigil, 2015, cited by Pinel, Pérez \&Carrión, 2019).

On the other hand, the consequences of work-related stress on interpersonal relationships accentuate the possibilities of aggressive behaviour: anxiety, tension, irritability, despondency, problems in coping with the responsibilities of a job, loss of professional self-esteem, job dissatisfaction, among others. Exhaustionis the most relevant factor of this syndrome, which is characterized by the fact that the subject during a stage of their life makes excessive physiological demands in the execution of their work functions, exceeding the permitted limit, which leads to emotional exhaustion reflected in the lack of energy, fatigue, wear and tear, anxiety, tension and frustration at work (Pelay, 2019). In this sense, emotional exhaustion is one of the main variables that characterize stress, where the individual perceives a loss of enthusiasm, displeasure, a sense of abandonment, loss of interest in work that causes inefficiency and dissatisfaction with the assigned responsibilities, triggering negative reactions and emotions to the detriment of the psychosocial and occupational development of the person.

As for depersonalization, this dimension, which is considered a consequence of emotional exhaustion, is characterized by negative attitudes and responses charged with anger and irritability towards the subjects with whom they work, establishing relationships of detachment and indifference between them; which leads to the flourishing of feelings of cynicism, as well as an increase in work demotivation, negativism and pressure (Maslach, 2001; cited in Dorantes, Hernández \&Tobón 2018; Pelay, 2019).

In the dimension of lack of personal fulfilment, it is characterized by the proliferation of negativism that leads to an unfavourable and pessimistic assessment of the subject, which results in the weakening of good relations with the people who receive the service and co-workers, as well as the affectation in the fulfilment of their job functions, awakening feelings of job dissatisfaction that lead to the loss of love for work, lack of enthusiasm and satisfaction (Aris, 2009; cited in Dorantes, Hernández \&Tobón 2018; Pelay, 2019).

In this complex and conflictive educational context, the role of the teacher is transformed into a strenuous activity, with high rates of professional and personal frustration that lead to an increase in work-related stress, the main trigger of burnout syndrome, sometimes with symptoms that are imperceptible to the teacher (Dorantes, Hernández \&Tobón, 2018); Teachers are the channel for the delivery of education and are the ones who make the decisions; and who have the ability to identify problems in the institution, maintaining ethics and professionalism at all times, offering effective communication, and supporting initiatives and activities where all the agents involved participate.

\section{COVID- 19}

The discovery of the coronavirus $(\mathrm{CoV})$ dates back to the $1960 \mathrm{~s}$, it is noted that, the coronavirus including SARS-CoV-2, which originated in Wuhan, Hubei province, China is categorized as a Betacoronavirus belonging to the subgenus Sarbecovirus which establishes a probable link to bat origin (BatCoV RaTG13), as other studies allude to the pangolin as a likely intermediate host (Han \& Yang, 2020; Valencia 2020; Dietz, et al., 2020). (Han \& Yang, 2020; Valencia 2020; Dietz, et al., 2020). Regarding the pathology in the case of Covid-19, the vast majority of infected individuals present mild or moderate symptoms, and others do not present any symptoms at all, however, they tend to recover with the appropriate treatment so far available in the world.Among the policies of social distancing and preventive isolation adopted by several governments, including that of Colombia, to limit the transmission of COVID 19 are: the closure of educational establishments (Chi, et al., 2020); it should be added that this measure became a challenge for which the education sector was not prepared, moving from face-to-face to non-classroom education. In Latin America, this scenario is complicated by the disparity in the social and economic conditions of the population, which increases the digital divide for both learners and teachers (UNESCO, 2020).

This new challenge of virtual education requires educators to have digital educational resources, skills and specific competences, which were not necessarily part of their professional training. Moreover, this situation is exacerbated by the lack of reference models for virtual education aimed at pre-school and primary school students 
or student population without connectivity (UNESCO, 2020). Therefore, the effectiveness of virtual education includes the commitment of the teacher, the quality of the digital platform, the willingness and recurrence of interaction between students and the continuous assessment of knowledge; therefore, part of the success of the virtual modality depends on the knowledge that the teacher has about how virtual education is done, training in the implementation of appropriate online methodologies and their interaction in the learning processes, as well as the ability to create their own virtual educational resources, characteristics that not all teachers currently possess (OEI, 2020).

\section{Virtual Education}

The theory of connectivism is defined as the confluence of precepts studied and assumed from the epistemology of chaos, networks, complexity and self-organization. Based on this concept, connectivism considers the educational process as a complex system, which must face and overcome various obstacles, but which, in turn, by incorporating the theory of chaos, must establish meaningful relationships and connections between the different phenomena and strata that allow the establishment of didactic categories, which must reach their maximum development through the implementation of knowledge networks through technological means in order to contribute to the organization and proper institutional functioning and the training of learners (Cueva, García\&Martínez, 2019).

On the other hand, Rose (2017), defines Information and Communication Technologies (ICT) as the set of electronic communication devices, computers including hardware and software, among others, as well as the services and applications provided by these devices such as videoconferencing and virtual education (cited by Karam, Moreno, Mejía, Plazas \& Castillo, 2019). Therefore, in the knowledge society, ICT revolutionized the different fields of society, opening a door in education, since it enables the creation of programmes so that subjects have the opportunity to obtain information without limits of time and space and, in turn, allowing the rise of a new mode of study where physical presence in a campus is not required, thus providing a flexible opening of academic preparation according to the needs and availability of resources of the learner (Coll\&Monereo, 2008; cited in Vélez, 2020).

Similarly, the Ministry of National Education (2020) defines virtual education as the development of teachinglearning processes, which take place beyond cyberspace and can take place synchronously or asynchronously through the mediation of telematic networks. Virtual education, also known as online education, breaks with the schemes of a perfect correspondence between time, space and body and, with the integration of new technologies as a fundamental tool, seeks to respond to the economic, social and political demands of the context. In Colombia, virtual education is regulated exclusively for higher education through Decree 1295 of 20 April 2010, Chapter VI, which refers to distance and virtual programmes. This same decree specifies that children between the ages of 5 and 15 must be educated face-to-face, except for those who have some personal or social condition that prevents access to face-to-face education, but once this exception is over they must return to the face-to-face modality; therefore, for basic (primary and secondary) and secondary education there is no specific regulation to develop it virtually.

The Ministry of National Education of Colombia (2013) in the document ICT Competences for the Professional Development of Teachers presents the ICT competences that every teacher must develop in order to achieve a successful integration of ICT in the learning processes, among them are: technological, pedagogical, management; for this reason, the academic success achieved by the student depends largely on the tutor teacher, since it is he who guides the development of pedagogical processes implementing innovative and meaningful training activities by implementing active and participatory methodologies required in online education (Burbano et al., 2017; Marciniak\&Sallán 2018, cited by Mendoza, Burbano\&Valdivieso, 2019).

Consequently, the virtual teacher (tutor) requires certain conditions to fully and successfully perform his role, among these are: he must be an expert in the subject he teaches, his relevant work will be to motivate, guide and accompany the learner throughout his learning process in such a way that it enhances the assimilation and construction of knowledge in the student. Likewise, they must play their role as evaluators of learning through the implementation of autonomous, collaborative and cooperative virtual learning; effective management of online environments, academic activities mediated by ICT, among others, which is why the tutor teacher must be able to achieve a balance between their specific knowledge of the area and technical knowledge with that of mediator of educational processes through innovative and relevant didactics for virtual environments (Mendoza, et al., 2019).

With regard to the dimensions of virtual education, we have the pedagogical dimension, in which the entire structure of virtual education must be built; in such a way that the educational perspective is not lost, either by the prominence and idolatry of technology or by transferring exactly the model of face-to-face education to the virtual one (Ministry of National Education, 2010); This should promote the development of educational activities of both a synchronous nature where the educational actors have a meeting space, as in the case of videoconferencing, and allow asynchronous work in an autonomous manner that requires students to develop their sense of 
responsibility and freedom both in making decisions about what they wish to learn and in terms of the distribution of their educational work, without renouncing teacher-learner teamwork (Ministry of National Education, 2010).

The communicative dimension makes it possible for the premises and concepts of the pedagogical dimension to be transcribed into meaningful and dynamic languages that allow for the understanding and internalization of this information. Online education should seek to ensure reciprocal interaction between the learner, teacher and content through the design of tasks that promote the development of critical thinking and the implementation of various digital communication tools either integrated into educational platforms or those available in cyberspace (Ministry of National Education, 2010).

Regarding the technological dimension, it is possible if there is an adequate technological infrastructure to develop virtual programmes, which is why educational institutions must have relevant and sufficient technological resources that guarantee hardware and software devices, This requires information systems that include "systems for admissions and registration, financing, welfare, virtual classroom platforms, institutional portals, evaluation systems, online support, library access, databases and all others that the institution finds relevant to ensure the quality of its offer" (Ministry of National Education, 2010 p. 47).

The organizational dimension allows for the interlocking and teamwork of the other three dimensions. It is necessary for educational institutions that offer virtual education to have academic and administrative policies and guidelines for this modality, as well as solid internal regulations that allow for the establishment of relationships under the parameters of healthy coexistence and respect. It is essential to have an interdisciplinary team called the production cell, which is made up of at least the teacher, the pedagogical advisor, the person in charge of graphic design and the web master for design, which allows the production and development of the virtual programmes and courses taught. The smooth running of the educational processes must be guaranteed through the management of financial resources and an investment and sustainability plan.

\section{Method}

The research was framed in the mixed approach and sequential design, in its quantitative phase it was deductive-hypothetical, applied, with a non-experimental cross-sectional design and in its qualitative phase it was inductive, applied with a phenomenological-hermeneutic design. The study population consisted of 1093 teachers from official schools in Floridablanca. For the quantitative approach, a non-probabilistic accidental sample of 110 teachers was used, and for the qualitative approach, a non-probabilistic convenience sample of 10 teachers was used.

The data collection techniques used to measure the variables and categories Burnout Syndrome, COVID-19 and Virtual Education were the survey and the interview. For the quantitative approach, we used the adaptation of instruments such as the Revised Teacher Burnout Questionnaire (CBP-R), the COVID-19 Pandemic Impact Survey, the Self-Assessment Questionnaire for Virtual Continuing Education Courses and were validated by the judgement of 10 experts and the reliability was measured with the Cronbach's Alpha coefficient.

Table 1. Reliability of instruments

\begin{tabular}{|l|c|}
\hline Questionnaire & $\begin{array}{c}\text { Alfa de } \\
\text { Cronbach }\end{array}$ \\
\hline Revised Teacher Burnout Questionnaire (CBP-R) & 0,972 \\
\hline Pandemic Impact Survey COVID-19 & 0,801 \\
\hline $\begin{array}{l}\text { Self-Assessment Questionnaire for Virtual Continuing Education Courses } \\
\text { (COVID) }\end{array}$ & 0,959 \\
\hline
\end{tabular}

Source: Ownelaboration (2021)

For the qualitative approach, an interview guide containing the three categories to be measured was prepared and validated by the judgement of 10 experts. Data processing and analysis was based on the theoretical foundations of statistics, using SPSS and the Atlas Ti programme. It should be noted that, in carrying out this study: copyright, key informants' voluntariness, privacy and confidentiality of the data were respected, therefore, the researcher did not alter or manipulate the data obtained in the research.

\section{Results}

\subsection{Quantitative results}

Based on the general objective, the quantitative results are shown by means of three tables in which the definitive percentage mean is reflected to measure the relationship between the variables under study: 
Table 2. Variable: BurnoutSyndrome

\begin{tabular}{|l|l|l|}
\hline $\begin{array}{l}\text { Descriptive Statistics of the } \\
\text { Dimensions: }\end{array}$ & Indicators & $\begin{array}{l}\text { Media } \\
\%\end{array}$ \\
\hline Job Stress & Role stress & 3,8 \\
\hline \multirow{3}{*}{ Emotionalexhaustion } & Tiredness and Fatigue & 3,1 \\
\cline { 2 - 3 } & Anxiety and Tension & 3,0 \\
\cline { 2 - 3 } & Frustration at work & 2,7 \\
\hline \multirow{3}{*}{ Depersonalization. } & Cynicism & 1,7 \\
\hline \multirow{3}{*}{ Lack of personal fulfilment. } & Negativism and pressure & 2,5 \\
\hline \multirow{3}{*}{ Disorganization } & Enthusiasm & 2,6 \\
\cline { 2 - 3 } & Satisfaction & 2,4 \\
\hline Administrative problems & Supervision & 3,1 \\
\cline { 2 - 3 } & OperationalConditions & 3,3 \\
\hline & Professional Concern & 3,5 \\
\cline { 2 - 3 } & Lack of professionalrecognition & 3,8 \\
\hline
\end{tabular}

Source: Ownelaboration (2021)

When analyzing the variable: Burnout Syndrome, starting from the descriptive statistics of the dimensions and taking into account the average percentage of the various tables, it is observed that the work stress dimension in its role stress indicator obtained 3.8\%; in the emotional exhaustion dimension, the indicator with the highest percentage is tiredness and fatigue with $3.1 \%$; likewise in the depersonalization dimension, the highest percentage was negativism and pressure with 2.5. Likewise, in the dimension lack of personal fulfilment, the enthusiasm indicator obtained $2.6 \%$, being higher than the satisfaction indicator; in the disorganization dimension, the operational conditions indicator obtained 3.3\%, being higher than supervision; and in the administrative problems dimension, the lack of professional recognition obtained 3.8\%, being higher than professional concern.

Table 3. Variable COVID-19

\begin{tabular}{|l|l|l|}
\hline $\begin{array}{l}\text { Descriptive Statistics of the } \\
\text { Dimensions: }\end{array}$ & Indicators & $\begin{array}{l}\text { Media } \\
\%\end{array}$ \\
\hline \multirow{4}{*}{ Pathology } & Propagation and symptoms & 3,9 \\
\cline { 2 - 3 } & Diagnosis and treatment & 4,3 \\
\cline { 2 - 3 } $\begin{array}{l}\text { Impact of the pandemic on } \\
\text { education }\end{array}$ & Security measures & 4,3 \\
\cline { 2 - 3 } & Impactonlearning & 3,4 \\
\cline { 2 - 3 } & InstitutionalCommunication & 3,3 \\
\cline { 2 - 3 } & Role of parents & 4,2 \\
\cline { 2 - 3 } & Schooldropout teachers and & 3,2 \\
\cline { 2 - 3 } & $\begin{array}{l}\text { Psychological impact on } \\
\text { students }\end{array}$ \\
\cline { 2 - 3 } & Job Stress & 3,8 \\
\hline
\end{tabular}

\section{Source: Ownelaboration (2021)}

When observing the analysis of the Covid-19 variable; starting from the descriptive statistics of the dimensions and taking into account the percentage average of the various tables, it is noted that in the pathology dimension, the indicators with the highest percentage average are those referring to diagnosis and treatment and Safety measures, both with $4.3 \%$ and the lowest is the one referring to propagation and symptoms and security measures; in the dimension impact of the pandemic on education, the indicator with the highest percentage is Role of parents with $4.2 \%$, surpassing the rest of the indicators as can be seen in table 3 .

Table 4. Variable Virtual Education

\begin{tabular}{|l|l|l|}
\hline $\begin{array}{l}\text { Descriptive Statistics of the } \\
\text { Dimensions: }\end{array}$ & Indicators & $\begin{array}{l}\text { Media } \\
\%\end{array}$ \\
\hline \multirow{3}{*}{ Pedagogical } & Instructionaldesign & 2,7 \\
\cline { 2 - 3 } & Digital competence of the teacher & 1,9 \\
\cline { 2 - 3 } & Student digital competence & 2,2 \\
\hline \multirow{3}{*}{ Communicative } & Teacher-studentinteraction & 2,6 \\
\cline { 2 - 3 } & Digital educationalresources & 2,1 \\
\cline { 2 - 3 } & Communicationchannels & 3,3 \\
\hline Technological & Technologicalinfrastructure & 2,0 \\
\cline { 2 - 3 } & Informationsystems & 2,2 \\
\hline
\end{tabular}




\begin{tabular}{|l|l|l|}
\hline & Security and privacy & 2,3 \\
\cline { 2 - 3 } Organizational & Maintenance & 2,0 \\
\hline & $\begin{array}{l}\text { Academic and administrative policies and } \\
\text { guidelines for virtual education }\end{array}$ & 1,9 \\
\cline { 2 - 3 } & Regulations, virtual programmes & 2,2 \\
\cline { 2 - 3 } & Organisationalstructure & 1,9 \\
\cline { 2 - 3 } & Productioncell & 1,3 \\
\cline { 2 - 3 } & Financialinvestment & 2,0 \\
\hline
\end{tabular}

Source: Ownelaboration (2021).

In relation to the virtual education variable, in the pedagogical dimension, the instructional design indicator scored 2.7, exceeding the average of the rest of the indicators; in the communicative dimension, the Communication channels indicator scored 3,3\%, with the highest average percentage of the other indicators. Likewise, the technology dimension, in its Security and privacy indicator, has a 2,3\%, being the highest percentage compared to the other indicators; in the case of the organizational dimension, the Regulations, virtual programmesis the highest percentage with $2,2 \%$ before the other indicators. The hypothesis test was carried out by applying Spearman's correlation coefficient and the research hypothesis can be accepted if the value of P-Values is $<0.05$.

Table 5. Correlation of variables

\begin{tabular}{|c|c|c|c|}
\hline Hipót & Variables & $\begin{array}{c}\text { Correlation } \\
\text { esis } \\
\text { Spearman }\end{array}$ & $\begin{array}{c}\text { Sig. } \\
\text { (bilateral) }\end{array}$ \\
\hline $\mathrm{H}_{1}$ & Burnout Syndrome-Virtual Education &,$- 565^{* *}$ &, 000 \\
\hline $\mathrm{H}_{\mathrm{i}}$ & Work stress - Virtual Education &,$- 590^{* *}$ &, 000 \\
\hline $\mathrm{H}_{\mathrm{ii}}$ & Emotional exhaustion - Virtual Education &,$- 495^{* *}$ &, 000 \\
\hline $\mathrm{H}_{\mathrm{iii}}$ & Depersonalization - Virtual Education &,$- 558^{* *}$ &, 000 \\
\hline $\mathrm{H}_{\mathrm{iv}}$ & $\begin{array}{c}\text { Lack of personal fulfilment - Virtual } \\
\text { Education }\end{array}$ &,,$- 487^{* *}$ &, 000 \\
\hline $\mathrm{H}_{\mathrm{v}}$ & Disorganization - Virtual Education &,$- 529^{* *}$ &, 000 \\
\hline $\mathrm{H}_{\mathrm{vi}}$ & Administrative problems &,$- 537^{* *}$ &, 000 \\
\hline
\end{tabular}

Source: Ownelaboration (2021).

Taking into account the results in table 5, the following statistical decisions were made:

H1: a correlation coefficient of -0.565 and a significance level of , 000 is evident which allows establishing an average negative correlation and, therefore, the null hypothesis is rejected and the alternative hypothesis is accepted. In other words, there is a significant inverse relationship between Burnout Syndrome in the framework of the COVID-19 pandemic and the virtualization of education in Colombian official school teachers - 2020.

\subsection{Qualitative results}

\section{Findings of the Burnout Syndrome category}

a) Subcategory Work stress: accumulation of work, lack of technological devices and connectivity of students and some teachers, overwork, need to deal with handling virtual platforms without having the appropriate preparation, among others.

b) Emotional exhaustion subcategory: longer working hours, physical problems at a muscular and optical level, physical and mental fatigue due to reviewing assigned work, receiving WhatsApp messages at different times of the day, anxiety about leaving home and facing virtual classes without proper preparation in their digital skills, mental fatigue due to recurring thoughts about the effectiveness of the education provided and the search for possible solutions, among others.

c) Subcategory Depersonalization: the majority did not express feelings of rejection and cynicism towards their students, except in two educational institutions where there was the irregularity of recounting a situation of indiscipline expressed by a student; presence of anger and irritability towards certain parents and students, pressure from parents and managers. 
d) Subcategory Lack of Personal Fulfilment: presence of motivation and enthusiasm to exercise their teaching profession despite the COVID-19 problem, presence of commitment to research and improve teaching practices, dissatisfaction with the quality of education provided during the pandemic due to limited technological resources and connectivity, as well as the lack of an instructional design and virtual educational platforms that would allow the development of quality pedagogical and evaluative processes.

e) Subcategory Disorganization: Divided positions with respect to supervision, some agreed that managers did their best to provide the necessary support while others highlighted the lack of supervision directed towards clear and precise goals and on the contrary oriented by uncertainty and lack of knowledge of what should be done. With regard to organizational conditions, there is evidence of physical and technological deficiencies in the schools, and a lack of the necessary work endowment to teach virtually from home.

f) Subcategory: Administrative problems: professional concerns are linked to the disinterest and lack of motivation of students for the development of school activities in the virtual context, lack of technological devices and the lack of internet connection of students, reserved educational quality provided given the circumstances of the pandemic, exposure on social networks or cyberbullying towards the teacher. The recognition of teachers is very limited by society, led by the government, which does not provide adequate conditions for teachers in terms of salaries, promotion system and health services, among others.

\section{Findings Category COVID-19}

The pandemic had a negative impact on the education sector, affecting the cognitive progress of students and therefore the effectiveness and quality of the education provided, institutional communication was inadequate, there was an increase in school dropouts, the mental health of students was affected due to the proliferation of episodes of anxiety, rebellion, apathy and frustration due to virtual study, and there were three cases of suicide attempts in students; parents took on the functions of a teacher, such as guiding and supervising academic processes, despite the fact that on some occasions they did not have academic and digital training and had to alternate these with their work responsibilities.

\section{Findings Category Virtual Education}

The limited technological infrastructure on the part of the students due to their low socio-economic status and the lack of virtual educational platforms in the educational establishments hindered the normal development of virtual education. In addition, the majority of teachers in the official sector did not have the pedagogical preparation or the digital competencies necessary for the development of their role as virtual teachers, which led to improvisation and the limitation of pedagogical and evaluative strategies, which became a burden for the teacher. Synchronous communication was reduced with a minimum hourly intensity and limited attendance due to the fact that most parents did not have a fixed internet plan, but had to recharge data so that their children could connect from a mobile phone.

\subsection{Discussion}

In response to the general objective of determining the relationship between Burnout Syndrome in the framework of the COVID-19 pandemic and the virtualization of education in Colombian official school teachers 2020 , and according to the quantitative data of the dimensions and indicators, where role stress experienced an average of $3.8 \%$, emotional exhaustion of $2.9 \%$, depersonalization of $2,1 \%$, lack of personal fulfilment of $2.5 \%$, disorganization of $3.2 \%$ and administrative problems of $3.6 \%$; The quantitative results show that $50.9 \%$ of the participating teachers presented the three components associated with the burnout syndrome (exhaustion, depersonalization and lack of personal fulfillment) at their moderate or high levels. With regard to the qualitative results, all the teachers showed an overload of work and a high level of physical and emotional exhaustion that had repercussions on both physical and emotional effects related to the improvisation and lack of technological and pedagogical resources for the exercise of quality virtual education.

The mental health of teachers is essential so that their work performance is not affected. During the pandemic, factors such as social inequalities came to light and became an obstacle for the official education sector to fully comply with its mission of offering quality education, as well as the weaknesses in teacher qualifications with respect to their modernization and training in technological competencies, which influenced Burnout Syndrome in teachers. The results of the study coincide with those obtained by Bedoya (2017) where the average Burnout score among teachers obtained a score of 43.4 as a significant figure of affectation among the participants. On the other hand, the results of the study by Zuniga (2018) indicate that globally the level of Burnout Syndrome is medium or low in the teachers of the educational institution where the research was conducted. However, with regard to the qualitative results, it can be said that care must be taken because all this contributes to teachers progressively developing Burnout or other psychosomatic pathologies that would harm their health, quality of life and family environment (Esteras, Chorot, Sandín, 2014, cited by Pinel, et al., 2019; Maslach and Leiter, 2016; Carlotto\&Gonçalves, 2019). 
In response to the first specific objective, which determines the relationship between the work stress dimension in the framework of the COVID-19 pandemic and the virtualization of education in teachers in official Colombian schools - 2020, it is highlighted in the quantitative results that the role stress indicator, in comparison with the other indicators, is experienced with an average of $3.8 \%$, classified as a high level; Therefore, teachers, daily handle the essential indicators of Burnout Syndrome, such as tiredness, decay, lack of incentive or initiative towards the performance of their duties, thus giving a minimization of their educational work, given by the pressure that develops from being exposed to the pandemic, coupled with the amount of psychosocial realities of the student body. Consequently, work stress in teachers was triggered primarily due to the lack of availability of technological devices and connectivity service for almost half of the students in the official sector due to their socio-economic status, as well as the lack of training in digital competencies that teachers had to take on the challenge of virtuality.

The quantitative findings of Martínez, Berthel and Vergara (2017) differ from those of the present study, in the results of the role stress indicator, $72 \%$ of the participants were at a moderate level, contrasting with the high level of this research. It should be noted that theories agree that this syndrome is maximized because different and diverse stressors are generated every day. This inverse proportionality relationship between work stress and virtual education coincides with the definition of work stress (Dorantes, Hernández and Tobón, 2018).

With reference to the second objective, which determines the relationship between the emotional exhaustion dimension in the framework of the COVID-19 pandemic and the virtualization of education in teachers in official Colombian schools - 2020; it stands out that in the emotional exhaustion dimension, with reference to the quantitative results, it presented an average of 2.9, placing this component at a medium level and the indicator with the highest percentage of an average of 3.1 at a moderate level, was tiredness and fatigue, but in the qualitative results the participants expressed a high level of the presence of this component, Therefore, the teaching staff are physically and psychologically exhausted, especially due to the excessive extension of their working day due to the need to provide virtual education without the relevant methodology and without the technological and didactic resources that this modality requires.

The profile of a professional, in this case a virtual teacher, and the availability of the necessary elements to carry out their work are decisive in order to successfully carry out their functions and avoid feeling exhausted when faced with a reality for which they are not prepared and without the necessary resources to do so. The results of the study coincide with those obtained by Zuniga (2018) and likewise, García, Marín, and Aguayo (2019) and Casanova, Mustelier, and Casanova, (2019), clarify that emotional exhaustion involves symptoms of loss of energy, physical and psychological exhaustion, fatigue, burnout and feelings of being at the limit, a fact that is corroborated in this study.

In response to the third objective, which determines the relationship between the depersonalization dimension in the framework of the COVID-19 pandemic and the virtualization of education in Colombian official school teachers - 2020. It can be said that, in terms of the depersonalization dimension, the average score was 2.1 considering a medium level; however, the qualitative results contrast with the quantitative results, since it was shown that this component is in the process of developing in the teachers in the sample, i.e. they did not express feelings of cynicism towards their students, except for two isolated cases of two teachers who expressed their feelings of rejection towards two students due to their acts of indiscipline; Another relevant qualitative result indicates that on several occasions they expressed feelings of irritability towards certain students and parents; it is therefore necessary to develop an atmosphere of sincerity, friendship and that they feel free to express their opinions about the pandemic and the pros and cons of virtual education. On the other hand, Zuniga (2018), García, et al., (2019) and Bedoya (2017), diverge with the results of this study, since they state that in the depersonalization scale the resulting mean does not coincide with those obtained in this study.

Virtual education given under appropriate and optimal conditions becomes an excellent option in a globalized world, but it is important to question the weakness it presents in terms of establishing emotional ties, especially when the student population at which it is aimed are children and adolescents, who are in the process of socialization and need to establish interpersonal relationships for their emotional growth, Similarly, teachers tend to maintain a considerable distance from their students in the virtual modality, which is reflected in a certain "coldness", perhaps due to the fact that they do not establish face-to-face communication, which means that they may gradually lose empathy, capacity for understanding or feelings of solidarity towards their students.

In response to the fourth specific objective, which determines the relationship between the dimension of lack of personal fulfilment in the framework of the COVID-19 pandemic and the virtualization of education among teachers in official Colombian schools - 2020, it can be seen that the quantitative results of the lack of personal fulfilment component have an average of $2.5 \%$. The qualitative results show feelings of enthusiasm and motivation for their vocation and teaching work despite the current health emergency caused by the pandemic, but also 
feelings of dissatisfaction at not being able to provide quality virtual education despite their efforts and dedication. In this sense, a significant number of teachers feel undervalued or disadvantaged by educational institutions or governing bodies, especially given the levels of demand imposed by the study modalities implemented in the midst of the COVID-19 pandemic. The pandemic situation allowed the teacher to awaken his investigative spirit and become a self-taught technologist who, although he did not reach competitive levels, did at least advance a little in his digital training, as well as allowing him to exploit his creativity to the maximum in order to find alternative solutions to the major obstacles he faced.

The results of the study contrast with those obtained by Zuniga (2018) who found that the incidence of this problem is rather low in relation to personal fulfilment at work. Garcia, et al., (2019) in their review work found similarities and differences at the same time with the results of this work. For his part, Bedoya (2017) states that in the scale of lack of personal fulfilment the results do not coincide with those obtained in this study. Having made the above considerations, two coincidences can be observed between the findings of this study in accordance with the contributions of Esteve (1994), Martínez, Valles and Kohen, (1997) cited by Jiménez and Arrieta (2017), since teachers present characteristics associated with job dissatisfaction, and in turn feelings of shared guilt for not being able to provide quality virtual education. Complementing the above, the results coincide with those expressed by Pelay (2019), who states that this dimension is characterized by the proliferation of negativism that leads to an unfavourable and pessimistic assessment of the subject, which results in the weakening of good relations with the people who receive the service and co-workers, as well as the affectation in the fulfilment of their job functions.

In the fifth objective, which determines the relationship between the disorganization dimension in the framework of the COVID-19 pandemic and the virtualization of education in Colombian official school teachers 2020 , it is quantitatively reflected that the disorganization dimension has an average of 3,2 and the supervision indicator hasan average of 3.1 per such; and from the qualitative data, the personnel consider that the operational conditions do not obey the biosecurity norms and do not have the technological capacity to offer quality virtual education. This means that a weakly organized institution is not very productive when implementing the virtual education modality, since the processes linked to it require rigour, thoroughness and dedication on the part of the staff, as well as adequate processes in terms of achieving the proposed goals.

Supervision must be in accordance with the appropriate leadership style to develop a more horizontal direction and that this pursues the welfare of teaching staff in terms of working conditions, healthy environment, infrastructure and furniture according to academic work and especially ergonomic, that is, that the workplace is in favour of the health of the individual (physiological, anatomical, psychological, educational), in terms of tools and specific tasks; and to manage fairly personal and interdepartmental interrelationships, otherwise, they become risk factors for the development of burnout syndrome.

The results of this study coincide in certain criteria with the findings of Cardozo and Yarel (2017) who state that an average of 37 teachers expressed that educational supervisors almost never develop principles such as accompanying rather than supervising, horizontality, objectivity, impartiality and transparency, professionalization, specialization and dignity of the teaching function. Likewise, the results coincide with the contributions of Jiménez, Hernández, and González (2000), since low-quality supervision devoid of personal, pedagogical, technological and administrative support for teachers, as well as excessive demands and little teacher participation in institutional decision-making, become risk factors for the development of Burnout syndrome.

With reference to the sixth objective, which determines the relationship between the administrative problems dimension in the framework of the COVID-19 pandemic and the virtualization of education in Colombian official school teachers - 2020; it can be said that the administrative problems dimension from the quantitative sphere had an average of 3.6, in which the professional concern indicator has an average of 3.5 and the lack of professional recognition of 3.8; Thus, it can be affirmed from a qualitative point of view that there are teachers who are concerned about professional development or growth, the maintenance of their work place and their income; on the other hand, teachers agreed that they receive little professional recognition, which means that despite an adequate performance of their work, they are not receiving incentives, promotions or incentives of any kind, despite performing their work adequately. Qualitatively, the results coincide with the contributions of Dorantes et al. (2018), because the existence of administrative problems and a bad working environment become factors that complicate the teaching role, as it becomes a strenuous and arduous activity, with high levels of professional frustration that lead to an increase in work-related stress, the main trigger of burnout syndrome.

Virtual education demands from the student processes of autonomy, self-discipline, self-control, responsibility, study habits, metacognition, among others, which in children and adolescents are still in the process of formation. In addition, it is necessary to review the effectiveness of public policies regarding the inclusion of ICTs in educational environments, strengthening the professionalization of teaching careers and mental health, as well as those referring to access to technology and connectivity for the most vulnerable sectors. The quantitative findings 
of Martínez, et al., (2017) coincide with those of the present study in the results of the lack of recognition indicator where $48 \%$ of the participants placed themselves at a high level and inthe Professional concerns indicator where $72 \%$ placed themselves at the medium level.

\section{Conclusions}

The effects of the pandemic have maximized the consequences of the aforementioned syndrome in the educational actors; in the sense that virtualization does not have sufficient educational quality since the official institutions do not have information systems, at least a virtual classroom platform and evaluation systems, therefore, this modality was not used correctly under correct technological platforms, where the student can interact effectively with the teacher, where there is continuous communication between them and exchange ideas and be able to evaluate academic activities accurately.

The stress of the role in this case is presented by the scarce didactic means to use in virtual classes and connectivity problems; this reality leads the teacher in this time of pandemic to believe that he will lose his health and the little support from his superiors and colleagues, modifying and forcing him to change his pedagogical practice to give answers to the whole virtualized educational process.

The state of exhaustion is the indicator that develops the most among their teaching activities in times of pandemic; due to the fact that, by increasing their excessive physiological demands, teachers maximize their physical and psychological tiredness, their emotional state, their general health and their increased interest in their work. Likewise, there are irregular situations of indiscipline, cynicism on the part of the teachers, as well as negativism and pressure, which is manifested through rejection of the students.

There is motivation and enthusiasm for the teaching activity, but dissatisfaction due to the fact that there is no certainty about the quality of the virtual education offered under the limitations of technological resources and connectivity caused by social inequality. Lack of support from the institution's management, inoperability of virtual education when there is no supervision directed towards clear and precise goals, and poor conditions for virtual education due to the institution's facilities. Likewise, there is a lack of interest and motivation of the students towards the fulfilment of school activities in the context of virtual education, the digital gap of their students and the effectiveness of the virtual education offered, as well as the fact that there are many demands on the teaching staff and there are no moments of recognition for their good work.

\section{References}

Bedoya, E., Vega, N., Severiche, C., y Meza, M. (2020). Síndrome de Quemado (Burnout) en Docentes Universitarios: El Caso de un Centro de Estudios del Caribe Colombiano. Formación Universitaria, 10(6), 51 -58. http://dx.doi.org/10.4067/S0718-50062017000600006

Carlotto, M. yGonçalves, S. (2019). Prevalence and predictors of Burnout Syndrome among public Elementary school teacher.Análise Psicológica, 2(37), 135-146. http://dx.doi.org/10.14417/ap.1471

Cardozo, O. yYarel, H. (2017). La supervisión educativa como elemento clave para alcanzar la calidad educativa

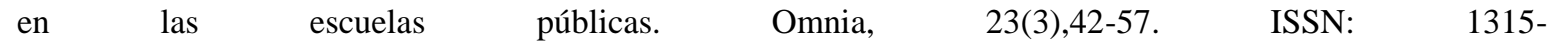
8856.https://www.redalyc.org/articulo.oa?id=737/73754947004

Casanova, C., Mustelier, M., y Casanova, T. (2019). Manifestaciones del síndrome de burnout, en docentes de la universidad de Cienfuegos. RevistaConrado, 15(66), 91-97. ISSN: 1990-8644.

Chi-Chung, V., Shuk-Ching W., Vivien Wai-Man, C., Yung-Chun, S., Hon-Kwan, J., Sridhar, ... J., KaiWang,T. (2020). The role of community-wide wearing of face mask for control of coronavirus disease 2019 (COVID-19) epidemic due to SARS-CoV-2.Elsevier, 41 , 1017-114. https://doi.org/10.1016/j.jinf.2020.04.024

Cueva, J., García, A., y Martínez, O. (2019). El conectivismo y las TIC: Un paradigma que impacta el proceso enseñanza aprendizaje. Revista Scientific, 4(14), 205-227.https://doi.org/10.29394/Scientific.issn.25422987.2019.4.14.10.205-227

Dietz, 1., Horve, P.F., Coil, D., Fretz, M., Eisen, J. y Van, K., Wymelenberg, D. (2020). 2019 Novel Coronavirus (COVID-19) Outbreak: A Review of the Current Literature and Built Environment Considerations to Reduce Transmission.mSystems, 5(3), 1-13. https://doi.org/10.1128/mSystems.00245-20

Dorantes, J., Hernández, J., y Tobón, S. (2018). Estado del arte del síndrome de burnout en docentes, mediante la cartografía conceptual. Praxis Investigativa ReDIE, 10(19), 57-77. ISSN-e: $2007-5111$. https://dialnet.unirioja.es/ejemplar/498549

García, M., Marín, M., y Aguayo, R. (2019). Burnout syndrome in secondary school teachers: a systematic review and meta-analysis. Social Psychology of Education, 22, 189-208. https://doi.org/10.1007/s11218018-9471-9 
Gil-Montea, P., Viottib, S., yConversob, D. (2017). Propiedades psicométricas del «Cuestionario para el Evaluación del Síndrome de Quemarse por el Trabajo» (CESQT) en profesionales de la salud italianos: una perspectiva de género. Liberabit, 23(2), 153-168. https://doi.org/10.24265/liberabit.2017.v23n2.01

Han, Y. y Yang, H. (2020). The transmission and diagnosis of 2019 novel coronavirus infection disease (COVID-19).A Chineseperspective. J Med Virol, 92, 639-644. https://doi.org/10.1002/jmv.25749

Jiménez, B., Hernández, E., y González, J. (2000). La evaluación del estrés y el burnout del profesorado: el CBPR. Revista de Psicología del Trabajo y de las Organizaciones, 16(2), 151-171. ISSN: 1576-5962. https://www.researchgate.net/publication/285131459_La_evaluacion_del_estres_y_el_burnout_del_profesora do_El_CBP-R

Jiménez, L., y Arrieta, M. Y. (2017). Síndrome de Burnout y evaluación de desempeño en docentes de la Fundación Universitaria del área andina sede Valledupar. Escenarios, 15(1), 36-46. Doi: http://dx.doi.org/10.15665/esc.v15i1.1120

Karam, J., Linares, L., Moreno, A., Mejía, F., Plazas, A. y Castillo, C. (2019). Las Tecnologías de la Información y la Comunicación en la Educación con Enfoque en América Latina. Revista Electrónica en Educación y Pedagogía, 3(4), 89-106. https://doi.org/10.15658/rev.electron.educ.pedagog19.03030406

Martínez, J., Berthel, Y., \& Vergara, M. (2017). Síndrome de Burnout en profesores y su relación con el aprendizaje de los estudiantes de básica primaria de una instituciñon educativa oficial de Sinceleljo (Colombia). Revista Salud Norte, 33(2), 118-128. http://dx.doi.org/10.14482/sun.33.2.10538

Martínez, O., Steffens, E. J., Ojeda, D. C., y Hernández, H.G. (2018). Estrategias Pedagógicas Aplicadas a la Educación con Mediación Virtual para la Generación del Conocimiento Global. Formación Universitaria,11(5), 11-18. http://dx.doi.org/10.4067/S0718-50062018000500011

Maslach, C. y Leiter, M. P. (2016). Chapter 43.Burnout. En Stress: Concepts, Cognition, Emotion, and Behavior,Handbook of Stress Series Volume 1 Elsevier, (351-356). https://www.sciencedirect.com/science/article/pii/B9780128009512000443

Mendoza, H. H., Burbano, V. M., y Valdivieso, M. A. (2019). El Rol del Docente de Matemáticas en Educación Virtual Universitaria. Un Estudio en la Universidad Pedagógica y Tecnológica de Colombia. Formación Universitaria, 12(5), 51-60. http://dx.doi.org/10.4067/S0718-50062019000500051

Ministerio de Educación Nacional. (2010). Lineamientos para la educación virtual en la educación superior. https://aprende.colombiaaprende.edu.co/ckfinder/userfiles/files/Lineamientos_para_la_educacion_Virtual_dic -29.pdf

Ministerio de Educación Nacional, (2013). Competencias TIC Para el Desarrollo Profesional Docente.https://www.mineducacion.gov.co/1759/articles339097_archivo_pdf_competencias_tic.pdf

Ministerio de Educación Nacional -Mineducación-. (mayo 9 de 2020). Educación virtual o educación en línea. https://www.mineducacion.gov.co/1759/w3article196492.html?_noredirect=1

Organización de Estados Iberoamericanos para la Educación, la Ciencia y la Cultura. (2020, 5 de mayo). Efectos de la crisis del coronavirus en la educación. https://www.flacsi.net/wp-content/uploads/2020/04/EFECTOSDE-LA-CRISIS-DEL-CORONAVIRUS-EN-EDUCACI\%C3\%93N.

Pelay, J. (2019). El síndrome de burnout. una mirada desde la cotidianidad docente. caso: escuela taller "Monseñor Arias Blanco". Prohominum Revista de Ciencias Sociales y Humanas, 1 (4), 18-37. e-ISSN: 2665-0169.

Pinel, C., Pérez, M. \& Carrión, J. (2019). Investigación sobre el burnout en docentes españoles: una revisión sobre factores asociados e instrumentos de evaluación. Bordón Revista de Pedagogía, 71(1), 115-131, https://doi.org/10.13042/Bordon.2019.62122

Presidencia de la República. (2010, 20 de abril). Decreto 1295. Por el cual se reglamenta el registro calificado de que trata la Ley 1188 de 2008 y la oferta y desarrollo de programas académicos de educación superior. https://www.mineducacion.gov.co/1621/articles229430_archivo_pdf_decreto1295.pdf

Rodríguez, J., Guevara, A., yViramontes, E. (2017). Síndrome de burnout en docentes. IE Revista De Investigación Educativa De La REDIECH, 8(14), 45 - 67. https://doi.org/10.33010/ie_rie_rediech.v8i14.39

UNESCO, (2020, 13 de abril ). Enseñar en tiempos del COVID-19. ISBN: 978-84-09-20986-6. https://unesdoc.unesco.org/ark:/48223/pf0000373868?_FB_PRIVATE_TRACKING_=\%7B\%22loggedout _browser_id\%22\%3A\%22c81c5d29f760c82e5f999c9eb6dac3df3ba17f42\%22\%7D

Valencia, D. N. (2020). Brief Review on COVID-19: The 2020 Pandemic Caused by SARS-CoV-2. Cureus 12(3), 1 - 15 https://doi.org/doi:10.7759/cureus.7386

Vélez, R. M. (2020). Retos de las universidades latinoamericanas en la educación virtual. Revista Virtual Universidad Católica del Norte, 59, 1-3. ISSN-0124-5821(En línea). https://doi.org/ 10.35575/rvucn.n59a1

Villamar, D., Juárez, A., y González., Moreno, M. (2019). Psychosocial Factors and Burnout Syndrome in Academics of a Public University from Mexico.Propósitos y Representaciones, 7(3), 111-140. http://dx.doi.org/10.20511/pyr2019.v7n3.360

Zuniga, S., y Pizarro, V. (2018). Mediciones de Estrés Laboral en Docentes de un Colegio Público Regional Chileno. Información Tecnológica, 29(1), 171-180. http://dx.doi.org/10.4067/S0718-07642018000100171. 
